\title{
Ipomoea brasiliana poisoning on buck reproduction
}

\author{
Ana Lizia Brito da Cunha ${ }^{1}$ Juliana Pinto de Medeiros ${ }^{2}\left(\right.$ Franklin Riet-Correa $^{3}$ Dale Gardner $^{4}$ \\ Hisadora Advíncula da Silva Chaves ${ }^{5}$ Givaldo Bom da Silva Filho ${ }^{5}$ Francisco de Assis Leite Souza ${ }^{5}$ \\ Joaquim Evêncio Neto ${ }^{5}$ Fábio de Souza Mendonça ${ }^{5 *}$.
}

${ }^{1}$ Programa de Pós-graduação em Medicina Veterinária, Universidade Federal Rural de Pernambuco (UFRPE), Recife, PE, Brasil. ${ }^{2}$ Centro de Ciências Biológicas, Universidade Federal de Pernambuco (UFPE), Recife, PE, Brasil.

${ }^{3}$ National Institute of Agricutural Research (INIA), La Estanzuela, Colonia, Uruguay.

${ }^{4}$ Poisonous Plant Research Laboratory, Agricultural Research Service, United States Department of Agriculture, Logan, UT, USA.

${ }^{5}$ Laboratório de Diagnóstico Animal, Departamento de Morfologia e Fisiologia Animal (DMFA), Recife, PE, Brasil. E-mail: fabio.mendonca@pq.cnpq.br. "Corresponding author.

ABSTRACT: Swainsonine-containing plants comprise a group of important poisonous plants in Brazil. This research aimed to characterize both the behavioral changes related to reproduction and appearance of lesions in the reproductive system of bucks poisoned by Ipomoea brasiliana. I. brasiliana plants were collected and administered at a dose of $4 \mathrm{~g} / \mathrm{kg}$ ( $800 \mu \mathrm{g}$ swainsonine/kg) to two groups of bucks for 45 days. Goats from Group I were euthanized on the $46^{\text {th }}$ day of the experiment, and goats from Group II were euthanized on the $120^{\text {th }}$ day. Group III was composed of goats that did not receive I. brasiliana and were euthanized on the $120^{\text {th }}$ day of the experiment. Reproductive behavioral changes were observed starting on day 20 and were characterized by an absence of courtship behavior, and Flehmen reflex, decrease or loss of libido and inability to perform mating. After 120 days, Group II goats showed no regression of the changes in their reproductive behavior or improvement of their seminal parameters. The main defects observed in the sperm of goats that consumed I. brasiliana were cytoplasmatic droplets, bent tails and detached tails. The main histopathological findings were reported in tests, with cytoplasmic vacuolization of germline and Sertoli cells, generalized impairment of spermatogonia maturation with exfoliation of degenerative cells, cell fragments, rare abnormal spermatocytes in the seminiferous lumen and disappearance of Leydig cells. Results of this study confirmed the hypothesis that I. brasiliana causes testicular degeneration in male goats.

Key words: alkaloids, lysosomal storage disease, plant poisoning, ruminants.

Efeitos da intoxicação por Ipomoea brasiliana na reprodução de caprinos

RESUMO: Este trabalho teve como objetivo caracterizar as mudanças comportamentais relacionadas a reprodução e lesões no sistema reprodutor de caprinos intoxicados por Ipomoea brasiliana. A planta foi coletada e administrada na dose de $4 \mathrm{~g} / \mathrm{kg}$ (800 $\mu \mathrm{g}$ swainsonina/kg) para dois grupos de caprinos durante 45 dias. Os caprinos do Grupo I foram eutanasiados no $46^{\circ}$ dia do experimento e os caprinos do Grupo II no $120^{\circ}$ dia. O Grupo III foi constituído por caprinos que não receberam I. brasiliana e foram eutanasiados no $120^{\circ}$ dia de experimento. Alterações comportamentais reprodutivas foram observadas a partir de 20 dias de experimento e consistiram em ausência do comportamento de corte, ausência de reflexo de Flehmen, diminuição ou perda de libido e incapacidade de realizar a monta natural. Após 120 dias, os caprinos do Grupo II não apresentaram regressão de alterações reprodutivas. Os principais defeitos observados no sêmen dos caprinos que consumiam I. brasiliana foram gotas citoplasmáticas, caudas dobradas e caudas destacadas. Os principais achados histopatológicos consistiram em vacuolização citoplasmática das células da linhagem germinativa e células de Sertoli; comprometimento generalizado da maturação das espermatogônias com esfoliação de células degeneradas; presença de fragmentos celulares e raros espermatócitos anormais no lúmen dos túbulos seminíferos e ausência de células de Leydig. Os resultados confirmam a hipótese de que o consumo de I. brasiliana causa degeneração testicular em caprinos.

Palavras-chave: alcalóides, doença de depósito lisossomal, planta tóxica, ruminantes.

\section{INTRODUCTION}

Swainsonine-containing plants comprise a group of several poisonous weeds that harm grasslands and impact animal husbandry development worldwide (COOK et al., 2014). These plants belong to three genera of the Fabaceae family (Astragalus, Oxytropis, and Swainsona) (BURROWS \& TYRL,
2012; COOK et al., 2009; COOK et al., 2013), one genus of the Convolvulaceae family (Ipomoea) and one genus of the Malvaceae family (Sida) (OLIVEIRA JÚNIOR et al., 2013). These plants are distributed in the United States, Canada, Mexico, Brazil, Russia, Spain, Ireland, Morocco, Egypt, Australia and China (JUNG et al., 2011; COOK et al., 2013; OLIVEIRA JÚNIOR et al., 2013). 
Ipomoea brasiliana (Mart. ex Choisy) Meisn., (previously reported as Ipomoea aff. verbascoidea and Ipomoea marcellia) (MENDONÇA et al., 2012; ROCHA et al., 2016), is a decumbent upright shrub that grows up to $1-5 \mathrm{~m}$ in height with oblong or oval-circular leaves and has solitary purple or lilac flowers (AUSTIN et al. 2015) and is an important poisonous plant of grazing livestock in the northeastern semi-arid region of Brazil (MENDONÇA et al., 2012; LIMA et al., 2013). Ipomea brasiliana is known to contain swainsonine and calystegines, two important toxins that are associated with the development of lysosomal storage disease in ruminants (COLEGATE et al., 1979; STEGELMEIER et al., 2008; MENDONÇA et al., 2012).

Swainsonine is an inhibitor of lysosomal $\alpha$-mannosidase, Golgi mannosidase II and other calystegines that are potent glycosidase inhibitors, and it is suggested that these inhibitors disrupt intestinal glycosidases, lysosomal function, and glycoprotein processing, leading to enzymatic dysfunction and accumulation of complex oligosaccharides in the lysosomes of nervous and epithelial cells (COLEGATE et al., 1979; DORLING et al., 1980; STEGELMEIER et al., 2008). Recent research has demonstrated that swainsonine is a fungal-endophyte-derived secondary metabolite and is not produced by the host plant. The presence of endophyte fungi has been demonstrated in species of Astragalus, Oxytropis, Swainsona and Ipomoea (BRAUN et al., 2003; PRYOR et al., 2009; HAO et al., 2012; COOK et al., 2013). However, it has been suggested that calystegines are secondary metabolites derived from plants because these toxins are present in plants derived from fungicide-treated seeds (COOK et al., 2013).

Clinical effects of Ipomoea spp. poisoning on the nervous system in ruminants and horses are well established in Brazil and are similar to those caused by other swainsonine containing plants worldwide. Despite causing a neurological syndrome, swainsonine-containing plants also have severe adverse effects on the reproductive function of livestock. All aspects of reproduction can be affected. Neurological dysfunction also inhibits normal reproductive behavior, and some of these effects are permanent and progressive (PANTER et al., 1989; PANTER et al., 1999; HUEZA et al., 2007; WU et al., 2016).

In this article, we aimed to characterize the clinical changes and microscopic lesions of the reproductive system of bucks poisoned by I. brasiliana.

\section{MATERIALS AND METHODS}

Leaves of Ipomoea brasiliana (voucher no. 50017) were collected in the municipality of Sertânia-PE (Figure 1A). Samples were dried in the shade and crushed in a mill until a powder was formed, and then, the powder was mixed and packed in plastic bags. The weight of the dried leaves represented $40 \%$ of the green leaves' original weight. concentration of swainsonine was determined from the pool of desiccated powder of $I$. brasiliana leaves as previously described by GARDNER et al. (2001).

In the experiment, nine male Saanen goats that were clinically healthy, aged 6-9 months and weighed between $16-21 \mathrm{~kg}$ were used. Goats were weighed at the beginning and end of the experiment to estimate the weight gain due to the media and standard deviation. Thirty days before the beginning of the experiment, goats received an antiparasitic medication, were randomly numbered and kept in individual stalls for adaptation and clinical observation. Early in the morning, goats received a commercial ration, mineral salt for goats, Tifton hay (Cynodon dactylon) and water ad libitum.

After the adaptation period, goats were randomly assigned to three groups: Group I goats received the powder of desiccated $I$. brasiliana leaves containing $0.02 \%$ swainsonine at a dose of $4 \mathrm{~g} / \mathrm{Kg}(800 \mu \mathrm{g}$ swainsonine/Kg) mixed in their feed over 45 days and were euthanized on the $46^{\text {th }}$ day of the experiment. Group II goats received the same daily dose of swainsonine for 45 days and were euthanized on the $120^{\text {th }}$ day of the experiment. Group III goats were the control group; these goats received the same type of management, but they did not receive I. brasiliana and were euthanized on the $120^{\text {th }}$ day of the experiment.

Goats of the three groups were examined in detail regarding their general condition, behavior, attitude, coordination, head posture, movement, appetite, mucous membrane color, rectal temperature, heart and respiratory rates, abdominal morphology, reticulum-rumen motility and physical appearance of their feces, urine and skin (RIET-CORREA et al. 2002; SMITH \& SHERMAN 2009). An andrological exam was performed routinely, semen was collected using an artificial vagina and the analysis included the concentration, structure and motility of their spermatozoa according previous description (HAFEZ \& HAFEZ, 2004). Values were expressed according to the mean; these means were compared by the Student's t test at 5\% significance. 
Before the beginning of the experiment, three andrological examinations were performed to verify the reproductive integrity of the animals. During the experiment, examinations were performed weekly, including general and physical examinations, palpation of the testicles, a behavioral examination to observe the presence of libido by observation of the courtship behavior and Flehmen reflex when placed next to a doe in heat, physical ability to perform a natural mount and spermogram.

For the determination of the serum testosterone levels, blood samples were obtained on the 15, 30, 45 days (Group I) and 15, 30, 45, 120 days (Group II and III) of the experiment. After centrifugation of $700 \mathrm{~g}$ of blood for 15 minutes, the serum concentrations of testosterone were analyzed using an Elisa kit (testosterone ${ }^{\circledR}$, Biochem Diagnostics, Inc., Ontario, Canada) that had an analytical sensitivity of $0.022 \mathrm{ng} / \mathrm{mL}$, centesimal precision and intra-assay coefficient of variation of $9.6 \%$.

For the histological characterization of the lesions, fragments of the male reproductive tract were routinely processed for a histopathology examination, immersed in methacrylate and stained with hematoxylin-floxin (TOLOSA, 2003). For morphometric analysis, 15 seminiferous tubules from each goat were photographed under microscopy with a 10x objective, after which the photomicrographs were used to measure the tubular diameter by means of ImagLab 3000 software. Duncan's Post-Hoc normality test was used for statistical analysis using ASSISTAT Version 7.7 beta software (2013).

\section{RESULTS}

Reproductive behavioral changes were observed starting on day 20 of the experiment in Group I and II goats. These changes were not uniform in goats from the experimental groups. One goat from Group I and two goats from Group II showed an absence of courtship behavior, absence of the Flehmen reflex, decrease or loss of libido and inability to perform mating. The remaining goats, despite the inability to perform mating, presented an abnormal courtship behavior, Flehmen reflex and libido. From the $20^{\text {th }}$ to $34^{\text {th }}$ days, the neurological clinical signs in both Group I and II were mild, and between the $35^{\text {th }}$ and

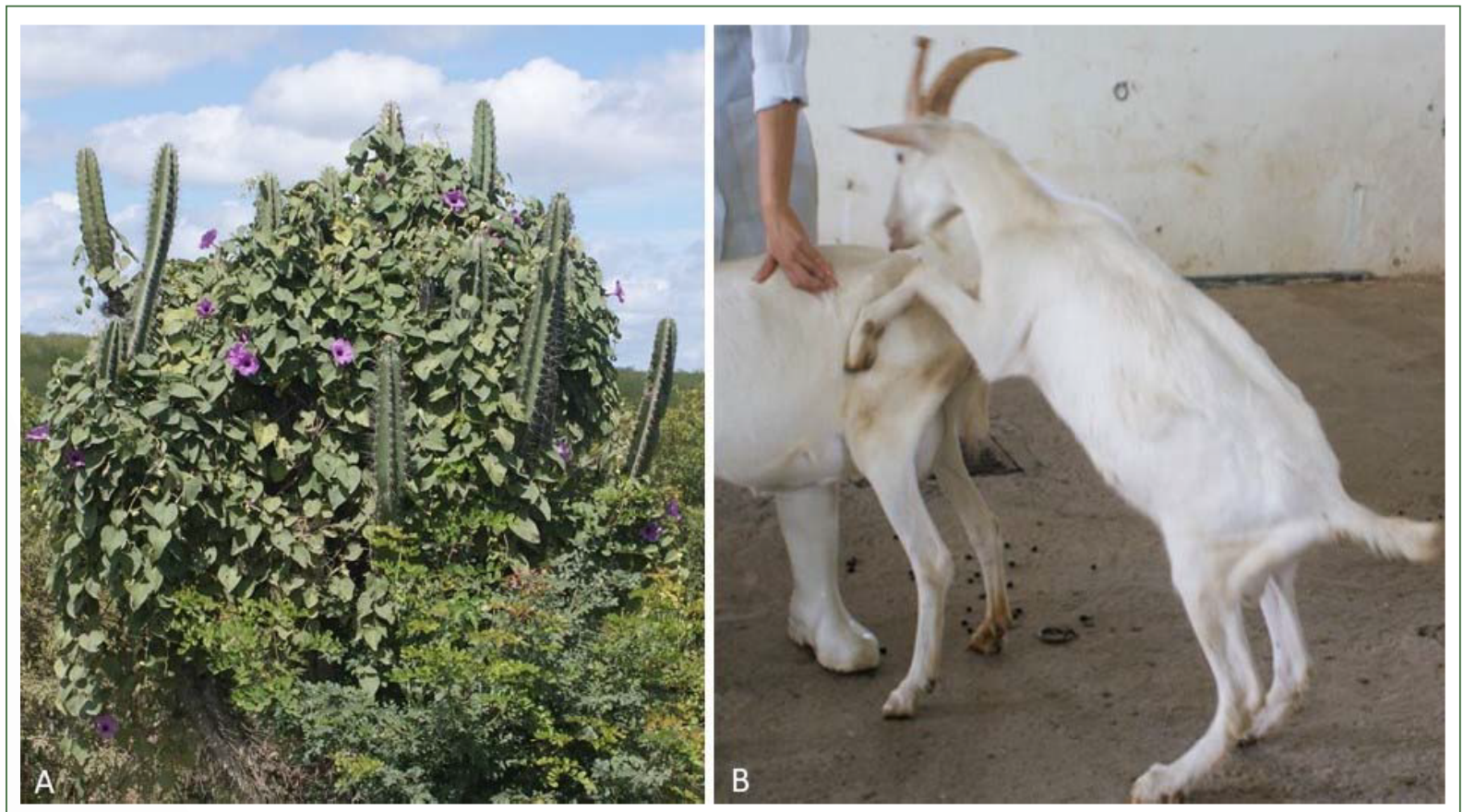

Figure 1 - (A) Ipomoea brasiliana is a decumbent upright shrub up to 1-5m in height, with oblong or oval-circular leaves, solitary purple or lilac flowers, Municipality of Sertânia, Pernambuco, Brazil. (B) Group I buck on the $20^{\text {th }}$ day of the experiment still demonstrating libido, but with difficulty to perform natural mating. 
$37^{\text {th }}$ days of the experiment, all goats presented severe clinical signs that were compatible with lysosomal storage disease; the main observed symptoms were motor incoordination, ataxia and dysmetria. These changes mainly resulted in the absence of libido and difficulty into mate (Figure 1B).

There was no significant difference related to the scrotal circumference between Groups I and II and the control group. There were also no changes related to the color and consistency of semen. The first changes in the seminal parameters, consisting of a discrete reduction of the semen volume and concentration of spermatozoa, were observed on the $14^{\text {th }}$ day of the experiment in Group I and II goats. During this same period, there were slight reductions in swirling, motility and sperm vigor. On the $21^{\text {st }}$ day of the experiment, these reductions were more severe and the number of major and minor defects in the spermatozoa were increased in goats poisoned by $I$. brasiliana. The main defects observed were cytoplasmatic droplets, prominent tails and bent tails. In group II goats, at 120 days of the experiment, there was no improvement related to the percentage of defects in the sperm morphology (Table 1).

Testosterone concentrations were statistically lower in the groups that received $I$. brasiliana than in the control group. Testosterone levels in the control group ranged from $15.1 \mathrm{ng} / \mathrm{mL}$ to $15.8 \mathrm{ng} / \mathrm{mL}$. In the groups that received I. brasiliana, the concentration of testosterone decreased on the $15^{\text {th }}$ day of the experiment to $10.9 \mathrm{ng} / \mathrm{mL}$ and $13 \mathrm{ng} /$ $\mathrm{mL}$ in Groups 1 and 2, respectively. Testosterone cooncentration decreased to $5.7 \mathrm{ng} / \mathrm{mL}$ and $5.9 \mathrm{ng} /$ $\mathrm{mL}$ on day 45 in Groups 1 and 2, respectively, and to $5.0 \mathrm{ng} / \mathrm{mL}$ at day 120 in Group II.

At necropsy, no significant lesions were observed in the testicles, epididymis, vas deferens, vesicular glands, prostate, bulbourethral glands or penis of goats from Group I, II or III. The main histopathological findings observed in Group I and II goats consisted of cytoplasmic vacuolization of the germline and Sertoli cells, generalized impairment of spermatogonia maturation with exfoliation of degenerative cells, cell fragmentation, rare abnormal spermatocytes in the seminiferous lumen and disappearance of Leydig cells. In Group II goats, the pattern of lesions was quite different because they did not include vacuolization of the germline and Sertoli cells. In addition to the severe exfoliation of the degenerative and germinative epithelium, other alterations were observed, including a reduction in the number of spermatogonia and spermatocyte layers, accumulation of proteinaceous material in the lumen of the seminiferous tubules and absence of epithelial cell stereocilia in the epididymis (Figure 2).

On morphometrical analysis, the diameter of the seminiferous tubules lumen was significantly increased in goats that received I. brasiliana compared to control goats (Table 2). Typical lesions of lysosomal storage disease were previously reported and found in the cells of the central nervous system and epithelia of the liver, thyroid, pancreas and kidneys in Group I goats. No vacuolization was noted in the CNS or in other organs examined in Group II goats. In Group II, the lesions were mild and were only observed in the cerebellum and frontal and parietal cortexes, and the lesions consisted of neuronal necrosis as evidenced by the presence of small cell bodies with an eosinophilic and angular cytoplasm and pyknotic nucleus. Some residual spheroids and gliosis were also observed in the cerebellar peduncles. Additionally, a hypothyroidism was observed in these group.

\section{DISCUSSION}

In this study, the absence of courtship and Flehmen reflexes and decreased or lost libido were the main changes in the reproductive behavior of goats that consumed I. brasiliana. These changes

Table 1 - Mean of the sperm parameters of Ipomoea brasiliana poisoned goats.

\begin{tabular}{lcccccccc}
\hline Group & SP $(\mathrm{cm})$ & Vol $(\mathrm{mL})$ & $\mathrm{C}(\mathrm{x} 106 \mathrm{sptz} / \mathrm{ml})$ & $\mathrm{MM}(0-5)$ & Mot $(\%)$ & $\mathrm{V}(0-5)$ & Major defects $(\%)$ & Minor defects $(\%)$ \\
\hline I & $20.3^{\mathrm{a}}$ & $0.4^{\mathrm{a}}$ & $1.1^{\mathrm{a}}$ & $2.1^{\mathrm{a}}$ & $39.9^{\mathrm{a}}$ & $2.1^{\mathrm{a}}$ & $4.1^{\mathrm{a}}$ & $3.5^{\mathrm{a}}$ \\
II & $19.3^{\mathrm{a}}$ & $0.5^{\mathrm{a}}$ & $0.9^{\mathrm{a}}$ & $1.5^{\mathrm{a}}$ & $26.6^{\mathrm{a}}$ & $1.6^{\mathrm{a}}$ & $6.4 \mathrm{~b}$ & $5.3 \mathrm{~b}$ \\
III & $20.0 \mathrm{a}$ & $1.0 \mathrm{~b}$ & $2.0 \mathrm{~b}$ & $4.4 \mathrm{~b}$ & $77.7 \mathrm{~b}$ & $4.4 \mathrm{~b}$ & $3.2^{\mathrm{a}}$ & $4.8 \mathrm{ab}$ \\
\hline
\end{tabular}

SP - scrotal perimeter, Vol - volume, C - concentration, MM - mass motility, Mot - motility, V - vigor. Ab Means followed by different letters in the same column differ from each other by Student's Test $(\mathrm{P}<0.05)$. 

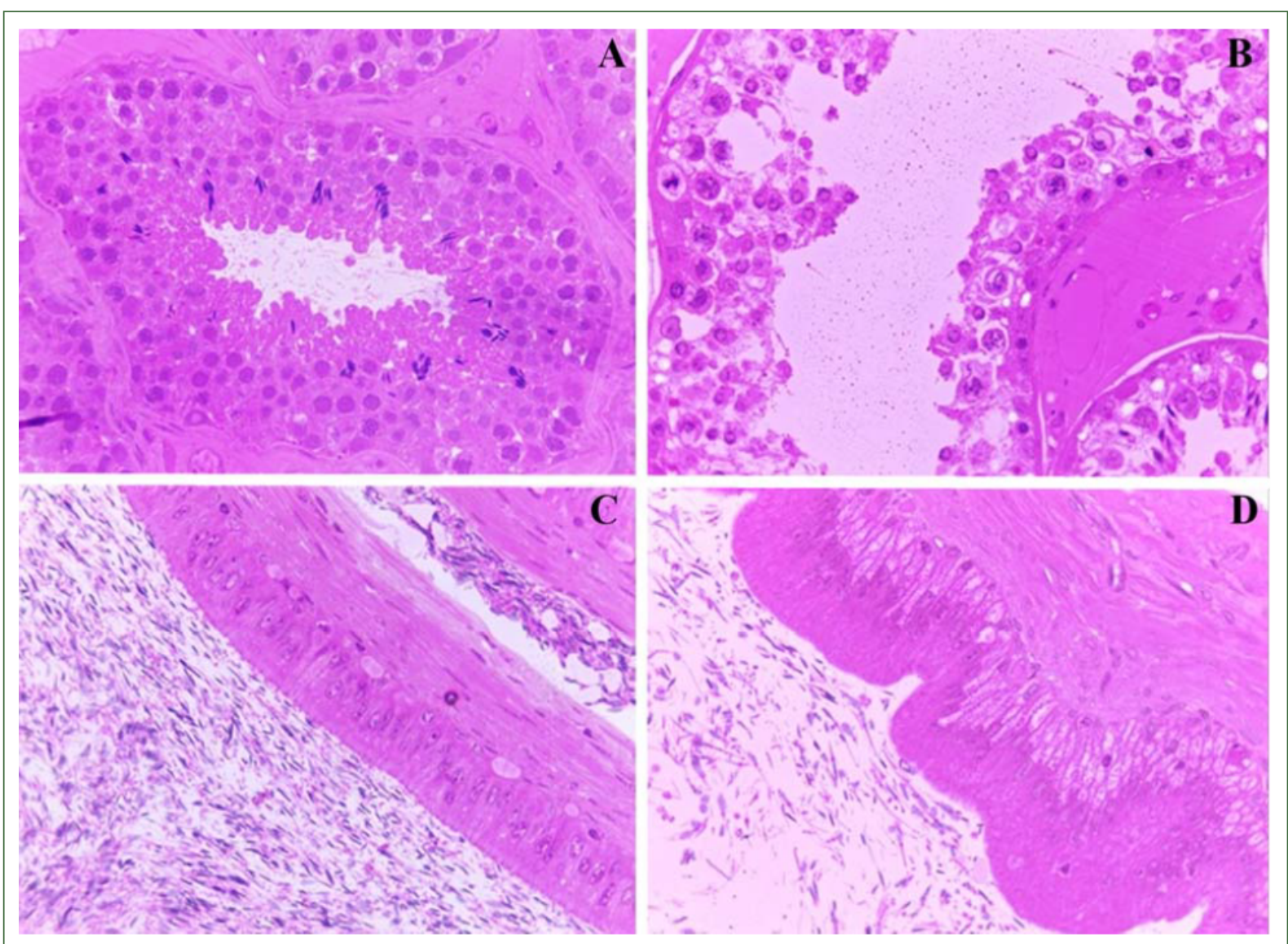

Figure 2 - Reproductive changes in goats poisoned by I. brasiliana. (A) Seminiferous tubules of control group with normal conjoined germinative epithelial cells and spermatozoa in the lumen. (B) Group II seminiferous tubules of goat with loss of cellular cohesion of the germinal epithelium, cytoplasmic vacuolization of spermatogonia and spermatocytes, sometimes with marginalized chromatin. (C) Epididymis of control group goat with intact epithelium and adequate concentration of spermatozoa in the lumen. (D). Epididymis of group II goat with cytoplasmic vacuolization of epithelial cells and oligospermia.

were identified before clinical neurological signs and were severe. The inability to perform natural mating, identified after the $20^{\text {th }}$ day of the experiment in Group I and II goats, probably represents the onset of cerebellar dysfunction, considering that severe clinical neurological signs, such as ataxia, hypermetria and motor incoordination, were only observed after the $35^{\text {th }}$ day of the experiment. Additionally, it is important to know that goats that consume Ipomoea spp. for more than 45 days demonstrated neurological sequelae because there was sufficient encephalic neuronal loss/death; although, cytoplasmic vacuolization was not present upon histopathological analysis (BARBOSA et al., 2007; 2007; LIMA et al. 2013). At this point, the reproduction of goats was completely impaired by neurologic disease. Cerebellar damage also affected muscular function and contributed to the inability to mount and breed.

The low quality of the buck's semen poisoned by I. brasiliana resulted from lesions and could be characterized as a generalized impairment of spermatogonia maturation with exfoliation of degenerative cells and loss of seminiferous tubule cell layers (as observed in Table 2), including a loss of type A1 spermatogonia. The main mechanism responsible for the testicular degeneration observed in those goats, even in Group II goats, is probably related to vacuolar degeneration in the thyroids and hypothyroidism, which impairs reproduction when a decreased levels of serum T3 and T4 are present (WILSON, 1975). This fact

Ciência Rural, v.48, n.10, 2018. 
Table 2 - Mean values and standard deviation of the diameter of the seminiferous tubules epithelial cells $(\mu \mathrm{m})$ of goats poisoned by Ipomoea brasiliana.

\begin{tabular}{lcc}
\hline Group & Mean & Standard Deviation \\
I & $54.5^{\mathrm{a}^{\mathrm{a}}}$ & \pm 0.7 \\
II & $46.9^{\mathrm{ab}}$ & \pm 1.2 \\
III & $81.5^{\mathrm{abc}}$ & \pm 1.9 \\
\hline
\end{tabular}

${ }^{* a b c}$ Different letters in the same column indicate statistically significant results. Duncan $\mathrm{p}<0.05$.

is more relevant considering that goats are more susceptible to hypothyroidism than other domestic animals (MANSON AND WILKINSON, 1973). Similar results were reported in a previous study in which an increase of pathological spermatozoa in goats poisoned by I. carnea was associated with a decreased concentration of thyroid hormones (GOTARDO et al., 2014).

In the pathogenesis of reproductive alterations, it is important to remember that swainsonine is highly soluble in water, rapidly diffuses through the bloodstream of ruminants, and inhibits lysosomal $\alpha$-mannosidases, lysosomal $\alpha$-mannosidases II and enzymes of glycoprotein metabolism, which results in abnormal hormones as well as changes in cell membrane receptors. Specific spermatozoa lesions are related to the molecular changes caused by swainsonine, which hinder cell adhesion, communication and cellular movements (PANTER et al., 1999; MOREMEN, 2002). Additionally, the toxic effects of calystegines may be involved in pathogenesis because they are strong inhibitors of glycosidases, mainly $\beta$-glucosidase and $\alpha$-galactosidase, and it has been suggested that, in vivo, calystegines are likely to disrupt lysosomal function and glycoprotein processing (STEGELMEIER et al., 2008).

Results presented in this study confirm the hypothesis that $I$. brasiliana causes reproductive changes in bucks. Certain reproductive parameters of males may be affected within two weeks, and other effects, such as testicular dysfunction, may go unnoticed, especially under open pasture grazing of the plant in the field. Other species of swainoninecontaining plants in Brazil, including I. riedelii, I. sericophyla, T. cordata and $S$. carpinifolia, may cause similar changes in the reproductive system of male goats.

\section{ACKNOWLEDGEMENTS}

We would like to thank the the Brazilian Agency Fundação de Amparo à Ciência e Tecnologia do Estado de Pernambuco (FACEPE) for providing a doctoral scholarship (Proc. IBPG-0760-5.05/09) and Coordenação de Aperfeiçoamento de Pessoal de Nível Superior (CAPES) (Finance Code 001).

\section{BIOETHICS AND COMMITTEE APPROVAL}

BIOSSECURITY

All applicable national and institutional guidelines for the care and use of animals were followed. The animal procedures were approved by the Ethics Committee on the Use of Animals (UFPE Process Number 23076.047266/2016-11).

\section{DECLARATION OF CONFLICTING INTERESTS}

The authors declare no conflict of interest. The founding sponsors had no role in the design of the study; in the collection, analyses, or interpretation of data; in the writing of the manuscript, and in the decision to publish the results.

\section{AUTHORS' CONTRIBUTIONS}

All authors contributed equally for the conception and writing of the manuscript. All authors critically revised the manuscript and approved of the final version.

\section{REFERENCES}

AUSTIN, D.F. et al. A synopsis of Ipomoea (Convolvulaceae) in the Americas: Further corrections, changes, and additions. Taxon, v. 64, p. 625-633, 2015. Available from: <https://doi.org/10.12705/643.14>. Accessed: Jan. 23, 2018. doi: 10.12705/643.14.

BRAUN, K. et al. Production of swainsonine by fungal endophytes of locoweed. Mycological Research, v.107, p.980-988, 2003. Available from: <https://doi.org/10.1017/S095375620300813X>. Accessed: Jan. 20, 2018. doi: 10.1017/s095375620300813x.

BURROWS, G.E.; TYRL, R.J. Toxic Plants of North America. Ames: Iowa State University Press, 2012. 1390p.

BARBOSA, R.C. et al. Experimental swainsonine poisoning in goats ingesting ingesting Ipomoea sericophylla and Ipomoea riedelii Ipomoea riedelii (Convolvulaceae). Pesquisa Veterinária Brasileira, v. 27, p.409-414. Available from: <http://130.211.64.33/ pdf artigos/04-11-2007 15-30Vet\%20421.pdf $>$. Accessed: May 09, 2018 . doi: 1590/S0100-736X2007001000004.

COLEGATE, S.M. et al. A spectroscopic investigation of swainsonine: an $\alpha$-mannosidase inhibitor isolated from Swainsona canescens. Australian Journal of Chemistry, v.32, p.2257-2264, 1979. Available from: <https://doi.org/10.1071/CH9792257>. Accessed: Jan. 20, 2018. doi: 10.1071/CH9792257.

COOK D. et al. Swainsonine-containing plants and their relationship to endophytic fungi. Journal of Agricultural and Food Chemistry, v.62, p.7326-7334, 2009. Available from: $<$ http://pubs.acs.org/doi/ipdf/10.1021/jf501674r $>$. Accessed: Jan. 20, 2018. doi: 10.1021/jf501674r. 
COOK, D. et al. Production of the alkaloid swainsonine by a fungal endosymbiont of the Ascomycete order Chaetothyriales in the host Ipomoea carnea. Journal of Agricultural and Food Chemistry, v.61, p.3797-3803, 2013. Available from: $<$ http://pubs.acs.org/doi/ ipdf/10.1021/jf4008423>. Accessed: Jan. 20, 2018. doi: 10.1021/ jf4008423.

COOK D. et al. Swainsonine-containing plants and their relationship to endophytic fungi. Journal of Agricultural and Food Chemistry, v.30, p. 7326-7334, 2014. Available from: <https://pubs.acs.org/ doi/10.1021/jf501674r>. Accessed: May 09, 2018. doi: 10.1021/ jf501674r.

DORLING, P.R. et al. Inhibition of lysosomal $\alpha$-mannosidase by swainsonine, an indolizidine alkaloid isolated from Swainsona canescens. Biochemistry Journal, v.191, p.649-651, 1980 Available from: <https://doi.org/10.1042/bj1910649>. Accessed: Jan. 20, 2018. doi: 10.1042/bj1910649.

GARDNER, D.R. et al. Analysis of swainsonine; extraction methods, detection, and measurement in populations of locoweeds (Oxytropis spp.). Journal of Agricultural and Food Chemistry, v.49, p.4573-4580, 2001. Available from: <http://pubs.acs.org/doi/ pdf/10.1021/jf010596p >. Accessed: Jan. 20, 2018. doi: 10.1021/ jf010596p.

GOTARDO, A.T. et al. Endocrine disrupter action in ruminants: A study of the effects -of Ipomoea carnea in adult male goats. Small Ruminant Research, v. 119, p.81-87, 2014. Available from: $<$ https:// www.smallruminantresearch.com/article/S0921-4488(14)00060-1/ pdf?code=rumin-site $>$. Accessed: May 09, 2018. doi: 10.1016/j. smallrumres.2014.02.003

HAFEZ, E.S.E.; HAFEZ, B. Reprodução animal. São Paulo: Editora Manole, 2004. 513p.

HAO, L. et al. Isolation and identification of swainsonineproducing fungi found in locoweeds and their rhizosphere soil. African Journal of Microbiology Research, v.6, p.4959-4969, 2012. Available from: <http://www.academicjournals.org/journal/ AJMR/article-abstract/F96FA9126138>. Accessed: Jan. 20, 2018. doi: 10.5897/AJMR11.1572.

HUEZA, I.M. et al. Effect of Senna occidentalis seeds on immunity in broiler chickens. Journal of Veterinary Medicine A Physiology Pathology Clinical Medicine, v.54, p.179-185, 2007. Available from: $<$ https://www.ncbi.nlm.nih.gov/pubmed/17493163>. Accessed: Jan. 20, 2018. doi: 10.1111/j.1439-0442.2007.00917.x.

JUNG, J.K. et al. Distribution of phenolic compounds and antioxidative activities in parts of sweet potato (Ipomoea batata L.) plants and in home processed roots. Journal of Food Composition and Analysis. v. 24, p.29-37, 2011. Available from: <https://doi. org/10.1016/j.jfca.2010.03.025>. Accessed: Jan. 23, 2018. doi: $10.1016 /$ j.jfca.2010.03.025

LIMA, D.D.C.C. et al. Doença de depósito lisossomal induzida pelo consumo de Ipomoea verbascoidea (Convolvulaceae) em caprinos no semiárido de Pernambuco. Pesquisa Veterinária Brasileira, v.33, p.867-872, 2013. Available from: $<\mathrm{http}: / / \mathrm{dx}$.doi org/10.1590/S0100-736X2013000700007>. Accessed: Jan. 20, 2018. doi: 10.1590/S0100736X2013000700007.

MANSON, R.; WILKINSON, J.S. 1973. The thyroid gland-a review. Australian Veterinary Journal, v. 49, p.44-49. Available from: $<$ https://onlinelibrary.wiley.com/doi/abs/10.1111/j.1751-0813.1973. tb14680. $x>$. Accessed: May 09, 2018.
MENDONÇA, F.S. et al. Alpha-mannosidosis in goats caused by the swainsonine-containing plant Ipomoea verbascoidea. Journal of Veterinary Diagnostic Investigation, v.24, p.90-95, 2012. Available from: <https://doi.org/10.1177/1040638711425948>. Accessed: Jan. 20, 2018. doi: 10.1177/1040638711425948.

MOREMEN, K.W. Golgi $\alpha$-mannosidase II deficiency in vertebrate systems: Implications for asparagines-linked oligosaccharide processing in mammals. Biochimica et Biophysica Acta, v.1573, p.225-235, 2002. Available from: <https://doi.org/10.1016/S03044165(02)00388-4>. Accessed: Jan. 20, 2018. doi: 10.1016/s03044165(02)00388-4

OLIVEIRA JÚNIOR, C.A. et al. Poisoning by swainsonine-containing plants in Brazil. Ciência Rural, v.43, p.653-661, 2013. Available from: $\quad<$ http://dx.doi.org/10.1590/S0103-84782013000400014>. Accessed: Jan. 20, 2018. doi: S0103-84782013000400014.

PANTER, K.E. et al. Transient testicular degeneration in rams fed locoweed (Astragalus lentiginosus). Veterinary and Human Toxicology, v.31, p.42-46, 1989. Available from: $<\mathrm{https}: / / \mathrm{www}$. ncbi.nlm.nih.gov/pubmed/2711606>. Accessed: Jan. 23, 2018.

PANTER, K.E. et al. Locoweeds: Effects on reproduction in livestock. Journal Natural Toxins, v.8, p.53-62, 1999. Available from: $<$ https:// www.ncbi.nlm.nih.gov/pubmed/10091128>. Accessed: Jan. 23, 2018.

PRYOR, B.M. et al. Undifilum, a new genus for endophytic Embellisia oxytropis and parasitic Helminthosporium bornmuelleri on legumes. Botany, v.87, p.178-194, 2009. Available from: $<$ https://doi.org/10.1139/B08-130>. Accessed: Jan. 20, 2018. doi: 10.1139/B08-130

RIET-CORREA et al. Importância do exame clínico para o diagnóstico das enfermidades do sistema nervoso em ruminantes e equídeos. Pesquisa Veterinária Brasileira, v.22, p.161-168, 2002. Available from: <http://www.scielo.br/pdf/pvb/v22n4/14290.pdf > Accessed: May 09, 2018. doi: 10.1590/S0100-736X2002000400006.

ROCHA, B.P. et al. Biópsia hepatica como método diagnóstico para intoxicação por plantas que contém swainsonina. Pesquisa Veterinária Brasileira, v.36, p.373-377, 2016. Available from: <http:// www.scielo.br/pdf/pvb/v36n5/1678-5150-pvb-36-05-00373.pdf>. Accessed: Jan. 20, 2018. doi: 10.1590/S0100-736X2016000500003.

SMITH, M.C.; SHERMAN, D.M. Goat medicine. New Jersey: Wiley-Blackwell, 2009. 888p

STEGELMEIER B.L. et al. The comparative pathology of the glycosidase inhibitors swainsonine, castanospermine, and calystegines A3, B2, and C1 in mice. Toxicology Pathology, v.36, p.651-659, 2008. Available from: $<$ https://doi.org/10.1177/0192623308317420>. Accessed: Jan. 20, 2018. doi: 10.1177/0192623308317420.

TOLOSA, E.M.C. et al. Manual de Téenicas para Histologia Normal e Patológica. São Paulo: Manole, 2003. 331p.

WILSON, J.C. 1975. Hypothyroidism in ruminants with special reference to foetal goitre. Veterinary Record, v. 97, p.161-164. Available from: <https://www.ncbi.nlm.nih.gov/pubmed/1101518>. Accessed: May 09, 2018.

WU, C. et al. The toxicology mechanism of endophytic fungus and swainsonine in locoweed. Enviromental Toxicology and Pharmacology, v.47, p.38-46, 2016. Available from: <http:// dx.doi.org/10.1016/j.etap.2016.08.018>. Accessed: Jan. 20, 2018. doi: 10.1016/j.etap.2016.08.018. 